\title{
certification program for consulting meteorologists
}

\section{The program as of 1982}

In an age of expanded environmental technology, the scope and detail of meteorological applications within agriculture, business, industry, and various sectors of government operations have brought increasing demands for specialized services by meteorologists. These services extended beyond the traditional public service functions and statutory responsibilities of the National Weather Service, and the private practice of consulting meteorology has developed in answer to some of the needs which arose. In meteorology, as in other technical professions such as engineering and medicine, individuals form and maintain close contact with the public, and in doing so are representatives of their profession. The AMS recognized a need for a professional certification program for the advancement of professional ideals within meteorology and within the other spheres of activity in which meteorologists participate. This certification in meteorology was to be a national program of the American Meteorological Society.

Such a Society program, to be administered by a Board of Certified Consulting Meteorologists, was conceived in a report submitted to the Council by the AMS Committee on Industrial Meteorology in the fall of 1956. The recommendation was approved with slight modifica. tions by the Council, which appointed a Board and also certified those first few members. The original announcement was made in the November 1957 BULLETIN. In a continuing effort to improve the program, the Board constantly assesses its procedures with an eye to providing the AMS membership with improved knowledge and understanding of the program, and to enhance the objectivity and fairness of the procedures. A review in 1981 led to some procedural modifications of a relatively minor nature and to a "codification" of the policies and procedures. These were published in the March 1982 BulletiN (pp. 317-319) and are incorporated in the information that follows to provide a wide understanding of the certification procedures.

As of July 1982 the Society has issued 326 certificates to those named in the appended list. A high percentage of the qualified persons whose principal endeavor was private practice of meteorology have applied for and earned the certificate. Recent years have shown increased interest in certification from salaried meteorologists employed in industry, universities, research institutions, federal laboratories, and state agencies. This evolution is a realistic reflection of the growth of applied meteorology as a profession; of the increasing number of professional, specialized services acknowledged as aspects of jobs in industry and government; and of broadening recognition by meteorologists that a certification program strengthens meteorology and the Society in ways that transcend types of employment and the previous narrow implications of private consulting for fee. Certification is gaining the same significance in meteorology that it has had in other technical professions for many years. In contrast with the limited view of consulting meteorology of only a decade ago, certification now applies to many branches of professional meteorology. The President of the Society in the January 1973 BULLETIN devoted his annual editorial to the relevance and vitality of the program. Beginning in February 1976, 15 essays on the meaning of the CCM program have appeared as a special series in the BULLETIN.

\section{Consulting meteorologist}

Fundamentally the consulting meteorologist is a professional meteorologist whose practice is founded upon an understanding of the atmosphere and its behavior, and upon his abilities acquired in applying this beneficially to the affairs of mankind. Moreover, these qualities are accompanied by wisdom of a more general nature that enables him to apply his specialized knowledge to a broader spectrum of related activities. Meteorological consulting may entail providing services individually to many clients on a fee-basis, or serving a company or government agency where such work comprises part or all the meteorologist's functions. In any case, the essential attribute of the certified meteorologist is a specialized knowledge combined with a broad background, an ingrained concept of service, and a clear and unwavering adherence to the rules of professional conduct.

\section{Purpose of certification}

The CCM program is a service for the general public by the American Meteorological Society. The Society has established high standards of technical competence, character, and experience for those who would seek to provide advice and consultation in meteorology to the public. The CCM Program was established to certify that certain individuals have been tested and found to meet or exceed those standards. The purpose is to enable users of meteorological services to select consultants or employees with greater confidence in the quality and reliability of the products or services they will receive.

Certification is a formal recognition on the part of his colleagues, acting through their Society, that an applicant is considered well qualified to carry on the work of a consulting meteorologist. The purpose of such certification is fivefold:

1) To foster the establishment and maintenance of a high level of professional competency, and mature and ethical counsel, in the field of consulting meteorology.

2) To provide a basis on which a client seeking assistance on problems of a meteorological nature may be assured of mature, competent, and ethical professional counsel. 
3) To provide incentive for the continued professional growth of the meteorologist after completion of his academic training.

4) To enhance the prestige, authority, success, and emoluments of consulting meteorology specifically, and of professional meteorology generally, by encouraging such a consistently high order of professional activity that unqualified practitioners will either labor to acnieve this recognition or retire from the field.

5) To provide a guide for eventual licensing of consulting meteorologists by state governments.

\section{Qualifications for certification}

The qualifications are centered about the fundamental characteristics of 1) knowledge, 2) experience, and 3) character. No one attribute can be considered sufficient unto itself, nor can excellence in any two compensate for a deficiency in the third; the three characteristics comprise a trinity of qualities that represent the goal to which an individual seeking this recognition should aspire.

Knowledge. To attain this recognition an individual should have a comprehensive, although not a detailed, understanding of the main aspects of meteorological knowledge. The role of specialization is recognized but the dangers of all depth and no breadth need to be clearly recognized. The work of a consulting meteorologist is to some extent in the nature of applied research. Thus, an understanding of research and the principles of scientific method, as well as demonstrated competence in applying these principles is a desirable characteristic. The role of formal education in acquiring knowledge is quite obvious but, also quite obviously, the two cannot be equated.

Qualification on basis of knowledge is, in first measure, indicated by college education including successful completion of courses in meteorology meeting national standards for professional employment. Lack of a college degree is not a bar to certification, and the doctoral degree does not command automatic certification, in the sense that degrees are incomplete measures of knowledge and of other attributes for certification. Applicants may expect a written examination on various aspects of science and the profession of meteorology.

Experience. The mature judgment and unostentatious selfconfidence that come from successful experience in applying knowledge to a useful end are recognized as requirements for maintaining proper stature in time honored professions. It applies here.

Qualification on basis of experience requires a minimum of five years of work at the professional level. Substitution of a post-graduate degree below the doctorate is permitted for one year of experience, and substitution of the doctorate degree in meteorology for up to two years is allowable. The nature of the work experience is an aspect considered.

Character. The character of the consultant must be of the finest and be manifest in devotion to the highest professional ideals. Relations with fellow meteorologists, and with clients or employers, should be conducted in a spirit of conforming in full to the Society's code of ethics.
In the matter of qualification on basis of character, the application requires the naming of at least three professional references, including one Certified Consulting Meteorologist. The applicant's record of professional work should clearly indicate that he or she maintains those traits for conduct complying fully with the Code of Ethics of the Society and applying generally in public contacts.

\section{Board of Certified Consulting Meteorologists}

This Board is a standing committee of the Society under the Commission on Professional Affairs. It is responsible for considering applications and making recommendations in regard to certification. The Board consists of five certified members ${ }^{1}$ who do not hold elective office in the Society and who contribute their time and interest to the program. No more than one member may be professionally employed by the same company during tenure on the Board. Members are appointed by Council action for terms of five years, with one term beginning each year. Actions of the Board are by majority vote and are reported to the Commission.

In order to ensure the fairness of the examination procedures, the Board has adopted the policy that its members will avoid conflicts of interest in the evaluation process. Members will continue to avoid such conflicts by disqualifying themselves from evaluating competitors or business associates when such relationships would interfere with their impartiality.

\section{Procedures for certification}

Application for designation as a Certified Consulting Meteorologist is made through the headquarters office of the Society. The application materials are then forwarded by that office to the Board for its consideration. The requirements are those expressed in the application form. Only those individuals with the necessary qualifications and dedication to the ideals of the program will be approved, for certification is meaningless of purpose if granted to all who attain membership in the Society. Certification is applicable to individuals only and not to organizations.

The procedures followed by the CCM Board are as follows:

1) An application form, with the appropriate nonrefundable fee, is submitted to the American Meteorological Society. The AMS, while retaining a copy of the

\footnotetext{
${ }^{1}$ The current composition of the Board is: John W. Wilson, Stone \& Webster Engineering Corp., Boston, Mass., Chairman; William H. Haggard, Climatological Consulting Corp., Asheville, N.C.; George E. McVehil, P.O. Box 4480, Boulder, Colo.; Dennis C. Perryman, Oceanroutes, Inc., 3260 Hillview Ave., Palo Alto, Calif.; Howard E. Reiquam, El Paso Natural Gas Co., El Paso, Texas.
} 
application, sends the original to the Chairman of the CCM Board. Headquarters staff requests letters of reference from the three names given by the applicant, one of whom will preferably be a CCM and one of whom will preferably be a former employer. The Chairman sends a letter of acknowledgment to the applicant and explains to him or her that a written examination will be assigned when all transcipts and letters of reference have been received. The Chairman, at his discretion, may also request additional letters of reference. As additional materials such as transcripts or letters of reference are received at AMS headquarters, staff will send all these materials (with four copies) to the Chairman on the first of each calendar month. It is then the Chairman's responsibility to follow up on missing items. Any unfavorable letters are immediately sent to AMS counsel for review.

2) The Chairman reviews and screens the application to ensure that the basic qualifications have been met. He then assigns a written examination. This usually consists of several standard questions intended to test the applicant's general meteorological background and several questions intended to probe more deeply his or her own area of specialty or expertise.

In order to improve the inventory of question and answer sets, highly qualified applicants (usually those who hold a Ph.D.) are asked to revise sets of questions previously submitted or to develop new ones.

A report, or published paper, representing the applicant's professional work is always required as part of the written assignment. This paper cannot be one which has been submitted for academic degree requirements. Additionally, applicants may be asked to prepare a short paper or essay on the CCM Program which may be considered for publication in the BULLETIN OF THE AMS. Such essays, however, are voluntary and are not graded formally.

A period of 90 days is normally suggested as sufficient to complete the written part of the examination. In practice, one or more time extensions may be given if an applicant has a need to request extra time.

3) On receipt of the completed written assignment, the Chairman removes from it any direct information which would identify the candidate. The exam and paper (and essay when requested) are then sent to all members of the Board without comment or other documentation. They are identified only by number.

4) Board members are instructed to assign a numerical score to each answer based upon their evaluation of the knowledge and methodology demonstrated by the candidate. Board members then determine an overall score in the range of 0 to 100 for the written examination.

The technical paper or report is similarly graded and given a numerical score between 0 and 100 . Papers are evaluated on the basis of the following criteria: identification of the (client's or research) problem, writing skill demonstrated, technical knowledge demonstrated, and objectivity and clarity of the writer's conclusion or recommendation.
5) Board members send the scores awarded the written exam and technical paper to the Chairman who determines the average score given on both the exam and the report. He then combines these scores giving twice as much weight to the written exam as to the technical report; that is, combined scores $S=\left(2 \bar{S}_{\text {(exam) }}\right.$ $\left.+\bar{S}_{(\text {paper })}\right) / 3$. A combined score below 60 is deemed a failure and there will be no oral review conducted for that applicant. The failed applicant's identity will remain confidential and the Commissioner on Professional Affairs will be advised prior to the Chairman notifying the applicant.

Following successful completion of the written examination, the Chairman forwards the following to each member who shall vote on the candidate's application:

a) composite score on the examination and paper, together with the identity of the candidate;

b) copies of the application;

c) all favorable letters of reference;

d) all favorable comments from any source;

e) all negative letters or comments previously approved by AMS counsel (those not sent to the Board Members will be retained in the permanent AMS files);

f) any other documents deemed relevant by the Chairman.

6) Board members then make recommendations with respect to oral reviews for each applicant based upon all the materials at hand, namely the academic records, work experience, composite scores, and letters of reference. If the applicant has been responsive to the instructions from the Chairman and has done a creditable job on his or her written assignment, and his or her written examination is consistent with his or her transcipts and letters of reference, the Board normally recommends that he or she meet with a "Regional Panel" for an oral examination. If, on the other hand, one or more Board members find cause for concern in the written materials they can request a "Board Members Only" oral review. The purpose of the Board Members review is to provide a more thorough evaluation of the applicant in question by the Board as a whole.

The chairman makes a final determination as to the type of oral review, based upon the Board's recommendations and all other materials in hand. All applicants must undergo an oral examination.

A Regional Panel consists of at least one current or recent (within the past three years) Board member and at least two other Certified Consulting Meteorologists. A Board Members Only Examining Panel consists of the Chairman and at least two other CCM Board members.

7) Scheduling of oral examinations is sometimes a significant delay in the certification process. Regional Panel exams are given at the mutual convenience of the applicant and the Board member who chairs the panel. The Board as a whole normally meets each year at the annual meeting of the AMS and on one other occa- 
sion. At these meetings, oral reviews as well as other Board business are conducted.

All applicants are advised in advance of the names of the members of the Board or Panel who will administer the oral exam. Any applicant may request that any member disqualify him or herself from the Panel for reasons of conflict of interest. The Chairman of the Board, however, reserves the final decision on all such requests.

All oral reviews consist of a discussion of the applicant's written examination materials, his or her technical report and any other topics deemed appropriate by the Panel. They always include discussion of hypothetical situations that arise in consulting activities.

Following each Board review or circulation of a brief report from a Regional Panel, the Board votes on its recommendation for each candidate. The ballot contains a statement that, "To the best of his knowledge, the voting Board member has no conflict of interest with this applicant." Results of the Board's vote are communicated to the Commissioner on Professional Affairs.

8) With the Commissioner's concurrence, names of applicants for whom the Board recommends certification are published in the BULLETIN OF THE AMS. In the usual case when no comments are received within 60 days after publication, the applicant is notified by the AMS that he or she has been certified and is sent his or her certificate.

Upon receipt of any negative comments following publication of a name, the Chairman will refer them to the Commissioner on Professional Affairs and to AMS counsel for review. Counsel can then approve distribution of these comments to the Board as a whole for further consideration. The Board can either reaffirm its earlier recommendation to certify or can initiate an investigation as to the validity of the comments and then reconsider its recommendation. The ultimate findings are then communicated to the Commissioner on Professional Affairs.

9) The master file on each applicant, upon completion of the Board's actions, is returned to the AMS for retention and all other copies are destroyed.

10) All unsuccessful candidates are allowed to reapply for certification two years from the date of denial of their application. Applicants not approved by the Board may appeal in writing within 90 days from the day the denial is issued to the Executive Committee, which may use a hearing officer or board in coming to its final decision.

11) Upon receipt of an application for renewal of certification, the AMS sends the application to the Chairman of the CCM Board for review. All CCM certificates shall be renewed upon application and payment of appropriate fees every five years, provided the applicant certifies that:

a) he or she has been actively engaged in the atmospheric, hydrospheric or related sciences for at least three of the preceding five years;

b) he or she has been a full member of the AMS in good standing for the past five years.

Following the Chairman's review and approval, the AMS notifies the applicant.

\section{Fees}

There is an application fee (which is $\$ 150$ in 1982) for certification. The application fee is not returnable.

\section{Renewal}

Certification is for a period of five years. In the application for renewal, the designee shall certify his activity in atmospheric, hydrospheric or related sciences during the preceding five years (see item 11 under Procedures). If the applicant has been inactive for three or more years, it may be necessary for him to satisfy the general requirements for certification. The fee for renewal is $\$ 30$ in 1982 . It is the responsibility of the office of the Secretary of the Society to notify designees of need to apply for renewal. If application for renewal is not received prior to the expiration date, complete application for certification may be necessary.

\section{Disciplinary action}

When it is brought to the attention of the Board in due processes in the Society that an individual holding this designation has demonstrated incompetence or has violated the rules of sound ethics, the certificate may be withdrawn and notice of such withdrawal shall be made in the Bulletin of the Society. Before such action, however, the designee shall have an opportunity to appear before the Board in proper defense. When certification is withdrawn, the certificate shall be returned to the Society.

On questions of ethics, the Board is free to consult with the Society's Board of Ethics, but it shall not be bound by the action of that Board, except that if the Council approves a recommendation by the Board of Ethics for withdrawal of Society membership from an individual, the certificate shall also be revoked. 
Certified Consulting Meteorologists

\begin{tabular}{|c|c|c|}
\hline Henry T. Harrison & May & 1957 \\
\hline Robert D. Elliott & June & 1957 \\
\hline Alfred H. Glenn & July & 1957 \\
\hline Joseph J. George * & Jan. & 1958 \\
\hline Woodrow C. Jacobs & Aug. & 1958 \\
\hline E. Wendell Hewson & Aug. & 1958 \\
\hline Loren W. Crow & Sept. & 1959 \\
\hline Wallace E. Howell & Sept. & 1959 \\
\hline Norman L. Hallanger & Sept. & 1959 \\
\hline Bernard N. Charles & Sept. & 1959 \\
\hline Jack W. Reed & Sept. & 1959 \\
\hline Werner A. Baum & Jan. & 1960 \\
\hline James M. Austin & Jan. & 1960 \\
\hline Robert D. Fletcher & Jan. & 1960 \\
\hline Frederic A. Berry * & Jan. & 1960 \\
\hline Arthur F. Merewether & Jan. & 1960 \\
\hline Helmut E. Landsberg & Jan. & 1960 \\
\hline John R. Murray & Jan. & 1960 \\
\hline Dennis W. Trettel & Jan. & 1960 \\
\hline Spencer Duckworth & Jan. & 1960 \\
\hline Eugene Bollay & Jan. & 1960 \\
\hline Howard T. Orville * & Jan. & 1960 \\
\hline John C. Bellamy & Aug. & 1960 \\
\hline Joseph A. Browne * & Aug. & 1960 \\
\hline Herbert Riehl & Aug. & 1960 \\
\hline Paul B. MacCready, Jr. & Aug. & 1960 \\
\hline Robert G. Beebe & Aug. & 1960 \\
\hline E. Brewster Buxton & Oct. & 1960 \\
\hline J. Vern Hales & Oct. & 1960 \\
\hline Bernhard Haurwitz & Oct. & 1960 \\
\hline Jerome Namias & Oct. & 1960 \\
\hline Vincent J. Schaefer & Oct. & 1960 \\
\hline Hurd C. Willett & Oct. & 1960 \\
\hline Edward J. Minser * & June & 1961 \\
\hline Jerome Spar & June & 1961 \\
\hline Edwin Kessler & Aug. & 1961 \\
\hline Morris Neiburger & Aug. & 1961 \\
\hline Milo J. Andre & Nov. & 1961 \\
\hline Louis L. Kolb ** & Feb. & 1962 \\
\hline Gordon B. Weir & Feb. & 1962 \\
\hline J. Murray Mitchell & Jan. & 1968 \\
\hline John E. Wallace & July & 1968 \\
\hline Sidney R. Frank & July & 1963 \\
\hline Richard E. Cale & Jan. & 1964 \\
\hline Walter J. Saucier & Aug. & 1964 \\
\hline Peter E. Kraght & Aug. & 1964 \\
\hline Howard E. Reiquam & Aug. & 1964 \\
\hline Thomas F. Malone & Oct. & 1964 \\
\hline Robert J. Grace* & Dec. & 1964 \\
\hline Harold W. Baynton & July & 1965 \\
\hline James R. Smith** & July & 1965 \\
\hline Norman F. Lacey & Mar. & 1966 \\
\hline Peter R. Leavitt & Mar. & 1966 \\
\hline
\end{tabular}

\footnotetext{
- Deceased.

* Inactive.
}

\begin{tabular}{|c|c|c|c|}
\hline 54 & Erwin K. Kauper & Mar. & 1966 \\
\hline 55 & Mark J. Schroeder & Mar. & 1966 \\
\hline 56 & Louis J. Battan & Mar. & 1966 \\
\hline 57 & Howard H. Hanks * & Mar. & 1966 \\
\hline 58 & Kenneth C. Spengler & Mar. & 1966 \\
\hline 59 & John E. Pearson ** & July & 1966 \\
\hline 60 & Albert Miller * & July & 1966 \\
\hline 61 & George F. Collins & Nov. & 1966 \\
\hline 62 & James B. Harrington, Jr. & Nov. & 1966 \\
\hline 63 & Robert M. White & July & 1967 \\
\hline 64 & Manuel E. Lopez & July & 1967 \\
\hline 65 & Leonard W. Snellman & July & 1967 \\
\hline 66 & John D. Ploetz** & July & 1967 \\
\hline 67 & Oskar M. Essenwanger & July & 1967 \\
\hline 68 & John T. Carr, Jr. & July & 1967 \\
\hline 69 & Richard M. Thuillier & July & 1967 \\
\hline 70 & Charles K. Stidd & July & 1967 \\
\hline 71 & Leo Alpert & July & 1967 \\
\hline 72 & Leslie F. Conover** & July & 1967 \\
\hline 73 & Earl G. Droessler & July & 1967 \\
\hline 74 & Clyde D. Martin & Nov. & 1967 \\
\hline 75 & Robert G. Read & Nov. & 1967 \\
\hline 76 & C. Eugene Buell & Aug. & 1968 \\
\hline 77 & Arlo W. Gambell, Jr. & Aug. & 1968 \\
\hline 78 & Edward M. Brooks & Aug. & 1968 \\
\hline 79 & Robert E. Bailey & Sept. & 1968 \\
\hline 80 & William W. Vaughan & Sept. & 1968 \\
\hline 81 & Harold L. Crutcher & June & 1969 \\
\hline 82 & Einar L. Hovind & June & 1969 \\
\hline 83 & John T. Walser & June & 1969 \\
\hline 84 & Donald H. Pack & June & 1969 \\
\hline 85 & Norman L. Peterson** & June & 1969 \\
\hline 86 & John K. Allison & Aug. & 1969 \\
\hline 87 & John C. Freeman & Sept. & 1969 \\
\hline 88 & Archie M. Kahan & Oct. & 1969 \\
\hline 89 & Walter A. Bohan & Dec. & 1969 \\
\hline 90 & Ralph Papania, Jr. & Dec. & 1969 \\
\hline 91 & Hugh W. Church & Dec. & 1969 \\
\hline 92 & R. Robert Rapp & Jan. & 1970 \\
\hline 93 & William P. Lowry & Jan. & 1970 \\
\hline 94 & Edward J. Tschupp & Jan. & 1970 \\
\hline 95 & Charlotte J. Hopper & Jan. & 1970 \\
\hline 96 & Albert V. Duffield & Mar. & 1970 \\
\hline 97 & John P. Murphy & Mar. & 1970 \\
\hline 98 & Arthur Hilsenrod & July & 1971 \\
\hline 99 & John H. Aldrich & July & 1971 \\
\hline 100 & David J. Stowell & July & 1971 \\
\hline 101 & W. Boynton Beckwith & July & 1971 \\
\hline 102 & Donald P. McIntyre** & Oct. & 1971 \\
\hline 103 & August H. Auer, Jr. & Oct. & 1971 \\
\hline 104 & Albert K. Showalter & Jan. & 1972 \\
\hline 105 & D. Ray Booker & July & 1972 \\
\hline 106 & Joseph L. Goldman & July & 1972 \\
\hline 107 & Banner I. Miller * & July & 1972 \\
\hline 108 & George E. McVehil & July & 1972 \\
\hline 109 & Ronald L. Godbey & Nov. & 1972 \\
\hline 110 & James H. Meyer & Feb. & 1973 \\
\hline
\end{tabular}




\begin{tabular}{|c|c|c|c|}
\hline 111 & Alan I. Weinstein & Feb. & 1973 \\
\hline 112 & Norman E. Bowne & Feb. & 1973 \\
\hline 113 & James D. McQuigg & Feb. & 1973 \\
\hline 14 & William B. Moreland & Apr. & 1973 \\
\hline 15 & Harold P. Gerrish & Aug. & 1973 \\
\hline 16 & Alfred K. Blackadar & Aug. & 1973 \\
\hline 117 & Edward S. Epstein & Aug. & 1973 \\
\hline 118 & Eugene M. Wilkins & Aug. & 1973 \\
\hline 119 & Richard J. Reed & Dec. & 1973 \\
\hline 120 & Oscar Tenenbaum & Dec. & 1973 \\
\hline 121 & Bernard H. DeWitt & Jan. & 1974 \\
\hline 122 & David B. Spiegler & Jan. & 1974 \\
\hline 123 & Max W. Edelstein & Jan. & 1974 \\
\hline 124 & Vincent J. Valli*** & Jan. & 1974 \\
\hline 125 & William K. Widger, Jr.* & Jan. & 1974 \\
\hline 126 & Sydney J. Buckler** & Aug. & 1974 \\
\hline 127 & Robert T. Small & Aug. & 1974 \\
\hline 128 & Robert W. Schloemer & Aug. & 1974 \\
\hline 129 & George W. Nicholas & Oct. & 1974 \\
\hline 130 & William T. Kreiss & Oct. & 1974 \\
\hline 131 & Don S. Packnett & Oct. & 1974 \\
\hline 132 & Armand R. Iaccheo & Nov. & 1974 \\
\hline 133 & Allen H. Weber & Dec. & 1974 \\
\hline 134 & David B. Smith & Dec. & 1974 \\
\hline 135 & Thomas H. R. O'Neill & Dec. & 1974 \\
\hline 136 & John W. Wilson & Dec. & 1974 \\
\hline 137 & W. Alan Bowman & Dec. & 1974 \\
\hline 138 & Eugene A. Carter & Dec. & 1974 \\
\hline 139 & Joanne Simpson & Dec. & 1974 \\
\hline 140 & Sidney Teweles & Dec. & 1974 \\
\hline 141 & H. Dean Parry & Dec. & 1974 \\
\hline 142 & Robert H. Simpson & June & 1975 \\
\hline 143 & John G. Cronin & Aug. & 1975 \\
\hline 144 & George W. Reynolds & Aug. & 1975 \\
\hline 145 & Rue E. Rush & Aug. & 1975 \\
\hline 146 & Sergio Serra Castelan & Aug. & 1975 \\
\hline 147 & James D. Kangos * & Aug. & 1975 \\
\hline 148 & Gerald L. Barger* & Aug. & 1975 \\
\hline 149 & Jack F. Paris & Aug. & 1975 \\
\hline 150 & William H. Haggard & Aug. & 1975 \\
\hline 151 & Jerry D. Hill & Aug. & 1975 \\
\hline 152 & Gale F. Hoffnagle & July & 1976 \\
\hline 153 & Raymond J. Deland & July & 1976 \\
\hline 154 & Dennis C. Perryman & July & 1976 \\
\hline 155 & Valentine J. Descamps & July & 1976 \\
\hline 156 & Charles L. Bristor & July & 1976 \\
\hline 157 & Richard K. Dumbauld & Sept. & 1976 \\
\hline 158 & William C. Thompson & Sept. & 1976 \\
\hline 159 & Tsann-wang Yu & Sept. & 1976 \\
\hline 160 & Dharmbir Rai & Sept. & 1976 \\
\hline 161 & John P. Bradley & Sept. & 1976 \\
\hline 162 & Robert O. Weedfall & May & 1977 \\
\hline & Walter A. Lyons & June & 1977 \\
\hline
\end{tabular}

- Deceased.

- Inactive.

\begin{tabular}{|c|c|c|c|}
\hline 164 & Sepp J. Froeschl & June & 1977 \\
\hline 165 & Joseph Laznow & June & 1977 \\
\hline 166 & Fredric J. Mogolesko & June & 1977 \\
\hline 167 & David Atlas & June & 1977 \\
\hline 168 & William H. Klein & Aug. & 1977 \\
\hline 169 & Herbert D. Entrekin & Aug. & 1977 \\
\hline 170 & Albert D. Anderson & Dec. & 1977 \\
\hline 171 & R. Cecil Gentry & Dec. & 1977 \\
\hline 172 & John A. Ernst & Dec. & 1977 \\
\hline 174 & Charles W. Tibbitts & Mar. & 1978 \\
\hline 175 & Dennis A. Trout & Mar. & 1978 \\
\hline 176 & Roger A. Pielke & Mar. & 1978 \\
\hline 177 & Thomas A. Hales* & July & 1978 \\
\hline 178 & Robert G. Fleagle & July & 1978 \\
\hline 179 & Thomas J. Lockhart & July & 1978 \\
\hline 180 & Edwin X Berry & July & 1978 \\
\hline 181 & Kenneth R. Hardy & July & 1978 \\
\hline 182 & Elmer Robinson & July & 1978 \\
\hline 183 & Edward E. Hindman II & July & 1978 \\
\hline 184 & Amiram Roffman & July & 1978 \\
\hline 185 & Newton A. Lieurance & July & 1978 \\
\hline 186 & Dennis G. Baker & Nov. & 1978 \\
\hline 187 & C. David Whiteman & Nov. & 1978 \\
\hline 188 & Dean A. Wilson & Nov. & 1978 \\
\hline 189 & Robert K. Crane & Nov. & 1978 \\
\hline 190 & Patrick J. Harney & Jan. & 1979 \\
\hline 191 & Marshall A. Atwater & Jan. & 1979 \\
\hline 192 & Austin W. Hogan & Jan. & 1979 \\
\hline 193 & Volker A. Mohnen & Jan. & 1979 \\
\hline 194 & Carl W. Kreitzberg & Apr. & 1979 \\
\hline 195 & Jawad S. Touma & Apr. & 1979 \\
\hline 196 & Bruce A. Egan & Apr. & 1979 \\
\hline 197 & Robert D. Boudreau & Apr. & 1979 \\
\hline 198 & Walter D. Bach, Jr. & Apr. & 1979 \\
\hline 199 & Paul L. Moore & Apr. & 1979 \\
\hline 200 & James A. Shear & Apr. & 1979 \\
\hline 201 & Merlin W. Zook & Apr. & 1979 \\
\hline 202 & Theodore F. Fathauer & Apr. & 1979 \\
\hline 203 & Ronald T. H. Collis & May & 1979 \\
\hline 204 & Arthur N. Hull & June & 1979 \\
\hline 205 & Mitchell Wurmbrand & June & 1979 \\
\hline 206 & Conrad J. Mason & June & 1979 \\
\hline 207 & A. Roger Greenway & June & 1979 \\
\hline 208 & Phillip D. Thomas & June & 1979 \\
\hline 209 & Chin-Hua Huang & June & 1979 \\
\hline 210 & John W. Hathorn III & June & 1979 \\
\hline 211 & Aaron L. Zimmerman & June & 1979 \\
\hline 212 & Jiin-Lang Lee & June & 1979 \\
\hline 213 & Leonard G. Pardue & June & 1979 \\
\hline 214 & George D. Greenly, Jr. & June & 1979 \\
\hline 215 & Karl F. Zeller & June & 1979 \\
\hline 216 & John T. Prohaska & June & 1979 \\
\hline 217 & Yean Lee & June & 1979 \\
\hline 218 & Frank V. Melewicz & June & 1979 \\
\hline 219 & Robert L. Carnahan & June & 1979 \\
\hline 220 & Steven R. Marks & June & 1979 \\
\hline 221 & Robert S Dischel ** & June & 1979 \\
\hline & Spengler & June & 1979 \\
\hline
\end{tabular}


22

224 Shih-Ang Hsu

225 Joseph M. Sorge

226 David R. Maxwell

227 Jerry Pell

228 Timothy C. Spangler

229 Roland List

230 Robert C. Beebe

231 Thomas J. Keegan

232 William W. Hildreth, Jr.

233 Louis A. Hembree, Jr.

234 Colin K. Guptill

235 Alvin L. Morris

236 Eugene C. Grueber

237 Richard R. Boyd

238 Michael Blatt

239 Gene L. Wooldridge

240 Lloyd L. Schulman

241 Silvio G. Simplicio

242 John H. Humphrey

243 William E. Reifsnyder

244 K. W. Ruggles

245 Richard H. Dunk

246 Thomas J. Henderson

247 William D. Ohmstede

248 Arnett S. Dennis

249 Lyle E. Brosché

250 Vance A. Myers

251 Keith J. Brown

252 George N. Brancato

253 Chester W. Newton

254 James I. Metcalf

255 Richard B. Wilkens III

256 David A. Sullivan

257 Loren D. Nelson

258 J. David Martsolf

259 Romeo R. Sabatini

260 John H. Snooks

261 Richard A. Rothstein

262 Edmund Bromley, Jr.

263 Michael W. Chan

264 Donald Ballanti

265 H. Robert Swart

266 Eugene L. Peck

267 Stanley J. Krivo

268 Ross J. Dixon, Jr.

269 Jerry A. Williams

270 John F. Henz

271 Leon F. Graves
June

June 1979

June 1979

June 1979

July 1979

July 1979

Sept. 1979

Sept. $\quad 1979$

Sept. $\quad 1979$

Sept. 1979

Sept. 1979

Sept. $\quad 1979$

Sept. $\quad 1979$

Sept. $\quad 1979$

Sept. 1979

Sept. $\quad 1979$

Sept. $\quad 1979$

Sept. 1979

Sept. 1979

Sept. 1979

Sept. $\quad 1979$

Sept. $\quad 1979$

Sept. 1979

Sept. 1979

Sept. 1979

Sept. $\quad 1979$

Sept. $\quad 1979$

Oct. 1979

Nov. 1979

Dec. 1979

Dec. 1979

Mar. 1980

Mar. 1980

Apr. 1980

Apr. 1980

May 1980

May 1980

May 1980

May 1980

May 1980

July 1980

July 1980

July 1980

July 1980

July 1980

July 1980

July 1980

Aug. 1980

Aug. 1980
272 Kenneth B. McCool

273 James F. Yohn

274

275

276

277

278

279

280

281

282

283

284

285

286

287

288

289

290

291

292

293

294

295

296

297

298

299

30

301

302

303

304

305

306

307

308

309

310

311

312

313

314

315

316

317

318

319

320

321

322

323

324

325

326

S. T. Rao

David C. Guzewich

Kenneth J. Skipka

Charles E. Kitson

Allan H. Murphy

Russell W. Shaffer

Rodger G. Steen

Gerald W. Grams

Douglas J. Fulle

John E. Pinkerton

Juanito M. Ramirez

Paul M. Fransioli

Duane R. Goodman

Donald T. Jensen

Joseph T. Schaefer

Harvey M. Freese

J. Spenser Huston

Keith W. Johnson

Robert S. Ingram

Joseph A. Catalano

Fred Doehring

Perry J. Samson

Michael E. Guski

John R. Martin

George H. Taylor

Henry A. Chary

Perry W. Fisher

Russell C. Schnell

Robert F. Abbey, Jr.

Arthur Bass

Lowell Krawitz

Ralph E. Huschke

Glenn D. Hamilton

William R. Goodin

Richard J. Mancini

Richard J. Boyle

Jack M. Mercer

Roger Caiazza

James C. Clary, Jr.

Steven A. Root

Arthur Blackham

Patrick T. Brennan

Philip G. Stickel

Hua Wang

Clifton R. Bittle
Roger A. Nelson

Daniel J. McNaughton

Francis E. Courtney, Jr.

Paul D. Gutfreund**

Arnold L. Barnes, Jr.

William J. B. Pringle

George G. McComb, Jr.

Subramaniam SethuRaman
Aug. 1980

Aug. 1980

Aug. 1980

Sept. $\quad 1980$

Sept. $\quad 1980$

Sept. $\quad 1980$

Sept. $\quad 1980$

Nov. 1980

Nov. 1980

Nov. 1980

Nov. 1980

Nov. 1980

Feb. 1981

Feb. 1981

Feb. 1981

Mar. 1981

Mar. 1981

Mar. 1981

Mar. 1981

Mar. 1981

Mar. 1981

May 1981

May 1981

July 1981

July 1981

July 1981

July 1981

July 1981

July 1981

July 1981

July 1981

July 1981

July 1981

July 1981

July 1981

July 1981

July 1981

July 1981

Dec. 1981

Jan. 1982

Jan. 1982

Jan. 1982

Apr. 1982

Apr. 1982

Apr. 1982

Apr. 1982

Apr. 1982

1982

July 1982

July 1982

July 1982

July 1982

July 1982

July 1982

July 1982 